\title{
KETERTARIKAN MASYARAKAT TERHADAP BISNIS RITEL DI KOTA MEDAN
}

\section{ACHIRUDDIN SIREGAR}

Dosen

Sekolah Tinggi Ilmu Ekonomi ITMI

\begin{abstract}
ABSTRAK
Penelitian ini bertujuan untuk mengetahui bagaimana ketertrikan masyarakat berbelanja di pasar modern atau bisnis ritel di Kota Medan. Pendekatan penelitian yang digunakan dalam penelitian ini adalah dengan menggunakan pendekatan assosiatif. Variabel di gunakan dalam penelitian ini meliputi pasar modern dan pasar tradisional. Populasi dalam penelitian ini adalah masyarakat yang berbelanja di pasar modern di Kota Medan, sedangkan sampel dalam penelitian ini berjumlah 170 responden. Teknik pengumpulan data dalam penelitian ini adalah kuesioner, wawancara dan observasi. Teknik analisis data menggunakan pendekatan asosiatif dan analisis regresi berganda.

Hasil penelitian menunjukkan bahwa ada pengaruh positif dan signifikan antara variabel ketertarikan atau minat beli masyarakat pada pasar modern atau bisnis ritel, dimana hampir 70\% masyarakat tertarik untuk berbelanja di pasar modern dalam memenuhi kebutuhan hidupnya dan sisanya 30\% lagi berbelanja di pasar tradisional.
\end{abstract}

Kata Kunci : Bisnis ritel, minat beli masyarakat

\section{PENDAHULUAN}

Kota Medan yang memiliki potensi dan jumlah penduduk yang cukup besar, dimana pola konsumsi masyarakat cenderung tidak terkendali akan memberikan gambaran yang baik bagi para investor untuk mulai mengembangkan dan memasuki pasar dengan membuka usaha ritel yang diprediksi akan maju pesat. Jika dicermati, bisnis-bisnis yang prosfeknya bagus beberapa tahun terakhir ini di Indonesia khususnya di Kota Medan adalah bisnis yang terkait dengan konsumsi masyarakat, contohnya : Makro, Carrefour (Plaza Medan Fair), Deli Plaza, Thamrin Plaza, Medan Mall, Sun Plaza, Palladium Plaza, Medan Plaza, Ramayana Plaza,dan beberapa swalayan atau supermarket yang menyebar disetiap penjuru di Kota Medan.

Konsekuensi dari fenomena tersebut yakni pada konteks persaingannya dengan periteil lokal bahkan bagi para pelaku ritel (pasar) tradisional. Hal ini bukan berarti bahwa kehadiran mereka perlu dibatasi tapi yang penting yakni kebijakan pemerintah yang mengatur hubungan dan aturan main dalam mengharmoniskan hubungan antara ritel modern dan ritel tradisional dengan tetap mempertimbangkan dampaknya terhadap pergerakan sektor riil tanpa mengabaikan hilangnya identitas sosial ekonomi dan udaya bangsa. Sebenarnya wacana mengenai keharmonisan atau sinergiasi ritel modern dan tradisional ini sudah menjadi wacana sejak tahun 2001, namun hingga saat ini belum terlihatnya upaya konkrit yang bisa mewujudkan tujuan tersebut. Sebenarnya kondisi ini bukan yang pertama kali dihadapi oleh pasar tradisional. Menurut catatan Asosiasi Pedagang Pasar Indonesia (APPSI) tahun 70-an sampai awal tahun 80-an, seluruh pembeli (konsumen) kelas bawah hingga kelas atas, belanja di pasar tradisional. Pertengahan tahun 80-an sampai awal tahun 90-an mulai muncul pasar modern, seperti 
Ramayana, Matahari, Golden Trully, Hero. Sebagian konsumen atau pembeli beralih dari pasar tradisional ke pasar modern.

Tahun 90-an merupakan booming pasar modern. Masyarakat berbondongbondong ke pasar modern. Tahun 2000-an, pasar tradisional makin meredup. Apalagi dengan makin menjamurnya hypermarket yang notabene merupakan peritel-peritel raksasa dunia yang memasuki berbagai Negara di Asia yang salah satunya Indonesia dan khususnya di Kota Medan.Sebelum dikenal Hypermarket, sudah dikenal konsep Supermarket dan Mini Market. Namun tampaknya pasar tradisional tidak bisa digeseroleh Supermarket ataupun Mini Market. Lalu apa bedanya konsep Hypermarket, yang membuatnya berpotensi menggeser pasar tradisional, dan juga apa yang efeknya bagi kita sebagai penjual?

Secara umum, penelitian ini menggali lebih jauh dan menelusuri 2 hal yakni perkembangan perilaku konsumen (konsumsi) dan issu sinergi ritel modern dan pasar tradisional. Spesifiknya, penelitian ini mencoba menguji model pembentukan retailer interest pada kedua jenis ritel tersebut (modern dan tradisional), dengan menggunakan model Jones \& Reynold (2006) yang disesuaikan dan kemudian melihat perbedaan pembentukan ketertarikan pada kedua ritel tersebut.

Penelitian ini mencoba melihat sisi lain dari retailer interest dengan melakukan penekanan pada pembentukan (antecedent) dari retailer interest sekaligus berusaha memaparkan rekomendasi dalam upaya revitalisasi pasar tradisianal.

\section{KAJIAN TEORI}

\section{Respon Konsumen ( Retailer Interest )}

Retailer interest merupakan konstruk yang merefleksikan respon konsumen secara keseluruhan terhadap retailer yangpernah dikunjungi sebelumnya (Jones \& Reynold, 2006). Definisi ini merupakan penerjemahan dari definisi evaluasi keseluruhan konsumen terhadap sebuah obyek (produk, merek, retailer, dan sebagainya), yang dipaparkan oleh Anderson (1994) dam Fornell (1992). Kedua peneliti menyatakan kepuasan konsumen secara umum merupakan hasil evaluasi keseluruhan dari seluruh atribut yang ditampilkan oleh produk, merek ataupun retailer. Kesinambungan pelanggan terhadap retailer merupakan indicator penting bagi kinerja retailer dan diharapkan mampu menstimuli perilaku repatronage intention (Oliver, 1997 ; Szymanski and Henard,2001). Namun yang perlu dperhatikan adalah bahwa kepuasan pelanggan dalam perilaku berbelanja di retailer bukanlah merupakan jaminan untuk mendapatkan pelanggan yang benar-benar setia terhadap retailer tersebut.

Beberapa studi sebelumnya mengemukakan bahwa pelanggan dapat saja berpindah retailer walaupun mereka sudah terpuaskan (Buta,1996 ; Jones and Sasser,1995 ; Reese,1996). Bahkan kesadaran akan fenomena ini sudah disampaikan Faisson (1997) dengan menyatakan bahwa pelanggan akan mudah berpindah retailer apabila mereka sudah jemu walaupun mereka dalam kondisi terpuaskan. Pada kondisi tersebut pelanggan merasa tertarik lagi untuk mengunjungi retailer karena beberapa hal, seperti retailer tersebut menyajikan hal-hal yang monoton dan membosankan, banyaknya pesaing dengan menawarkan berbagai variasi pelayanan yang baru,dan lain sebagainya.Pelayanan yang membosankan tanpa adanya variasi pelayanan baru berpotensi menghilangkan ketertarikan pelanggan untuk berkunjung ke retailer tersebut ( Bond, 1996 ; Buss, 1997). 
Kondisi inilah yang kemudian menjadi isu menarik yang dikemukakan pada penelitian Jones dan Reynolds (2006). Namun beberapa hal yang tidak dipaparkan oleh kedua penulis yakni

Pertama. Tidak adanya penelusuran awal pembentukan konsep retailer interest. Kedua, beberapa pendekatan yang dilakukan menggunakan literature yang kurang relevan, konsep pengelolaan retailer. Untuk menjawab dua kekurangan tersebut, penelitian ini mencoba merekonstruksi kembali model penelitian Jones dan Reynolds (2006) dengan melakukan studi literature yang relevan dan studi eksplorasi dalam menemukan indicator pembentukan retailer interst sekaligus merekomendasikan beberapa hal yang dipandang perlu dalam revitalisas pasar tradisional.

\section{Utilitarian Value dan Hedonic Value}

Salah satu isu yang mengemuka dari riset-riset retailer yakni adanya pergeseran atau perubahan dratis dari fokus perhatian retailer terhadap utilitarian value menjadi lebih pada hedonic value (Arnold \& Reynold,2003).

Utilitarian Value merupakan nilai fungsional (utilitarian) yang dirasakan oleh konsumen terkait dengan pemenuhan kebutuhannya.Sedangkan Hedonic Value adalah nilai hedonis (emosi) yang dirasakan oleh konsumen pada saat akan, sedang atau telah mengkonsumsi suatu produk. Lebih lanjut dikatakan, retailer dewasa ini tidak hanya memenuhi kebutuhan utilitarian pelanggan melalui penawaran produk berkualitas dengan harga yang terjangkau tapi lebih pada pertanyaan "how to entertain them", Retailer Interest merupakan pernyataan kognitif yang merefleksikan motivasi atau keinginan dari pelanggan (Clore et al.,1987; Richins,1997). Pernyataan kognitif tersebut bisa dihasilkan oleh positive atau negative feeling. Lebih lanjut Mano \& Oliver (1993) memparkan kontribusi dari nilai utilitarian dan hedonik dlam perilaku belanja konsumen. Menurut mereka bahwauntuk menciptakan hubungan yang lebih kuat dengan pelanggan, maka sebaiknya para pelaku pemasaran (bisnis) sudah sepntasnya lebih mengedepankan nilai hedonic dan tidak hanya mengandalkan nilai utilitarian.

Wesley at al, (2006) memparkan bahwa pada berbagai jenis retailer atau pusat perbelanjaan, pola pengambilan keputusan dan motivasi serta alasan berkunjung akan berbeda-beda pula. Motivasi belanja konsumen pada berbagai situasi dan konteks berdampak pada evaluasi keseluruhan terhadap suatu retailer ( Tauber 1992 ). Motivasi ini kemudian sangat dipengaruhi oleh berbagai faktor, salah satunya yaitu: jenis retail atau pusat perbelanjaan (Wesley, 2006). Untuk memberikan gambaran yang utuh terhadap pembentukan konstruk retailer interest, kajian penelitian ini berawal dari pemahaman konsumen atau masyarakat untuk datang berbelanja ke retailer.

\section{Motivasi Berbelanja (Shopping Motives)}

Motivasi berbelanja konsumen pada berbagai situasi akan berpengaruh terhadap retailer. Motivasi berbelanja atau shopping motives merupakan salah satu unsur penting yang membedakan perilaku dan evaluasi konsumen terhadap retailer. Konsumen memiliki tujuan yang berbeda-beda untuk datang berkunjung ke retailer, misalnya : bersosialisasi, urusan bisnis, atau kegiatan lainnya yang tidak berkaitan dengan kegiatan berbelanja.

Shopping motives yang disampaikan Tauber (1992), terbagi atas 2 dimensi yaitu:

a. Induvidual motives (learn about new brand, self gratification,dll)

b. Social motives ( social experiences, peer group attracting, dll) 
Westbrook \& Black (1985) mengklasifikasikan shopping motives dalam 3 kategori yaitu:
a. Product oriented
b. Experiences oriented
c. Hybrid

Studi mengenai motivasi belanja dan atribut ritel merupakan area riset yang telah banyak dilakukan dalam 30 tahun terakhir. LaBay and Comm (1991) melakukan profiling light vs heavy pada konsumen factory outlet, mereka menemukan bahwa heavy users lebih menekankan pada price, brand names, shopping convenience and store location.

Sementara itu Karande and Ganesh (1998), memetakan outlet- Mall Shoppers berdasarkan motivasi belanja, sikap terhadap perilaku belanja dan tingkat kepentingan atribut retailer maka diperoleh tiga segmen konsumen yang muncul dalam perilaku belanja konsumen di mall yaitu:
a. Recreational shoppers
b. Serious economic shoppers
c. Time-Conscious/ deal-Prone shoppers

\section{Kondisi Faktual atau Lingkungan (Atmosphere)}

Ketertarikan pelanggan terhadap retailer (retailer interest) juga tidak terlepas dari bagaimana retailer memberikan pelayanan yang komprehensif dan ditampilkan dari kualitas pengelolaan store atmosphere-nya. Perlu dicatat bahwa focus perhatian pelanggan untuk berkunjung ke retailer telah bergeser lebih pada pemenuhan nilai hedonisnya bukan utilitarian.

Birtner (1990) menyatakan bahwa perencanaan retail atmosphere yang matang merupakan salah satu kunci menarik konsumen untuk datang mengunjungi retailer tersebut. Hal ini berarti retailer yang mampu mengelola dengan baik kreatif retail atmosphere-nya mempunyai peluang yang lebih baik untuk menstimuli pelanggan datang berkunjung, begitu pula sebaliknya.

Melengkapi pembntukan retailer interest, penelitian ini memasukkan retail atmosphere sebagai salah satu unsur pembentuk retailer interest menggunakan indikator yang diperkenalkan Bermans dan Evans (1995), yang menyatakan ada 5 faktor pembentuk retailer interest yaitu sebagai berikut :
a. Exterior
b. General interior
c. Lay-out
d. Interior display
e. Human variables

Spangenberg, Crowley and Henderson (1996), memaparkan bahwa psikolog terhadap lingkungan merupakan turunan dari paradigma Stimulus-Organism-Response (SOR). Dalam konteks ini store atmosphere merupakan stimulus dan evaluasi konsumen merefleksikan organisme, sedangkan perilaku belanja merupakan response yang diperlihatkan konsumen pasca evaluasi.

Psikologi lingkungan (environemental psychology) pada berbagai literatur mengindikasikan bahwa konsumen (shopper) merespon store atmosphere pada salah satu dari dua perilaku yaitu :
a. Avoidance
b. Approach 
Avoidance menunjukkan keengganan konsumen untuk tetap berada dalam retailer (toko) dan merefleksikan efek negatif dari store atmosphere yang dirasakannya. Sedangkan approach memperlihatkan efek positif dari store atmosphere yang memotivasi konsumen untuk terus dan berlama-lama berada dalam retailer (toko). Lebih lanjut De-Soriano \& Foxxal (2006), menemukan bahwa efek dari atmosphere (store place) terhadap perilaku belanja konsumen menghasilkan sikap mosional yang sangat kuat dan menjadi atribut prioritas bagi konsumen untuk datang berkunjung dan melakukan berbagai kegiatan ke retailer.

\section{Revitalisasi Pasar Tradisional}

Untuk lebih menajamkan temuan penelitian yang aka dipaparkan nantinya, maka peneliti melakukan observasi langsung serta menelusuri berbagai kebijakan tekait dengan pengelolaan ritel nasional ummnya dan pasar tradisional khususnya. Dari hasil pengamatan yang diperoleh peneliti,bahwa kebijakan terhadap penguatan eksistensi pasar tradisional sebagai salah satu pranata social bangsa asih sangat bersifat retorik dan belum menyentuh akar permaslahan. Contoh konkritnya yakni inkonsistensi dalam pengaturan lahan peruntukan. Belajar dari kehadiran ritel modern di awal 80-an dan 90an dengan munculnya berbagai supermarket dan minimarket sebenarnya dapat memberi kita arahan bahwa perlu adanya pengaturan yang jelas dari pihak regulator untuk mengharmoniskan hubungan pasar tradisional dengan pasar modern.

Di tahun 80-an dan 90-an pasar moderndalam bentuk supermarket dan minimarket masih cukup harmonis berdampingan dengan pasar tradisional karena adanya kebijakan mengenai harga jual dan target pasar yang dibidik oleh kedua jenis pasar tersebut berbeda. Namun sekarang dapat kita lihat kehadiran pasar modern dalam bentuk hypermarket dengan menyebar keseluruh lapisan masyarakat dengan harga yang dapat dibilang cukup murah menjadi salah satu ancaman yang dapat merongrong eksistensi pasar tradisional. Kekuatan permodalan yang dimiliki oleh para ritel raksasa dunia berdampak pada posisi tawar-menawar yang timpang dengan para suppliernya. Hal ini dapat dilihat oleh berbagai protes dari supplier di berbagai dunia cetak mengenai Trading Term yang ditetapkan oleh peritel besar tersebut.

Persoalan lain yang ditemukan penulis yaitu persoalan slogan-slogan kemitraan dengan UMKM dengan pasar modern tidak terlihat dengan nyata implementasinya. Hal ini juga merupakan salah satu alasan untuk mengkaji ulang berbagai kebijakan pengaturan bisnis ritel di Indonesia pada umumnya dan di Kota Medan pada khususnya. Belum lagi persoalan jarak kedekatan pasar modern dengan pasar tradisional sehingga dengan sendirinya akan terjadi peralihan konsumen besar-besaran yang perlahan-lahan dapat mematikan pasar tradisional.

Data dari Asosiasi Pedagang Pasar Indonesia (APPSI) menyebutkan adanya 400 hingga 500 los pasar yang tutup setiap tahunnya. Pekerjaan mendesak bagi pemerintah untuk segera mengeluarkan undang-undang yang mengatur perdagangan ritel nasional yang tetap menjamin keberlangsungan hidup pasar tradisional, pedagang-pedagang kecil dan mikro serta UMKM yang merupakan pilar ekonomi kerakyatan.

Potret di atas bukan berarti bahwa revitalisasi pasar tradisional menjadi tanggung jawab pemerintah saja, melainkan juga menjadi kewajiban bagi pelaku pasar tradisional untuk segera melakukan pembenahan diri dalam memperbaiki atmosfir pasar yang bersahabat dan memberi kenyamanan bagi para pengunjungnya. Dari segi pengelolaan pemerintah setempat hendaknya bekerja sama dengan dinas yang terkait sehingga diharapkan lebih profesional dan terarah, misalnya : melakukan tender 
kepengelolaan pasar tradisional kepada swasta atau menunjuk salah satu BUMD untuk melakukan pengelolaan pasr tradisional secara profesional.

Untuk memperjelas perbedaan antara pasar modern dan pasar tradisional dapat terlihat pada tabel 1 , berikut ini :

Pasar Modern vs Pasar Tradisional

\begin{tabular}{|l|l|l|}
\hline Karakteristik & Pasar Modern & Pasar Tradisional \\
\hline 1. Fisik Gedung & Eksklusif (AC, TI, & Terbatas \\
\hline 2. Infrastruktur & $\begin{array}{l}\text { Lengkap } \\
\text { Escalator,Evalator,Parkir, } \\
\text { Information desk, Cleaning } \\
\text { Service,Security,dll) }\end{array}$ & \\
\hline 3. Pengelolaan & Swasta/Profesional & Pemda/Konvensional \\
\hline 4. Interaksi & Informatif & Informatif \& Bargaining \\
\hline 5. Attitude Pedagang & Well Educated & Less Educated \\
\hline
\end{tabular}

\section{Kerangka Konseptual}

Motivasi belanja konsumen yang terbentuk oleh faktor pemenuhan kebutuhan sehari-hari ( role shopping), faktor harga yang relatif murah dan kebiasaan tawarmenawar (value shopping) serta menjadi tempat untuk berinteraksi dengan kerabat dekat bahkan dengan para pedagang di pasar tersebut (social shopping) menjadi pemicu bagi responden untuk terus berkunjung ke pasar tradisional. Disamping itu store atmosphere sangat mempengaruhi respon konsumen untuk berkunjung dan tertarik berbelanja. Selanjutnya hubungan utilitarian yang akan merefleksikan berbagai manfaat yang diperoleh ketika berkunjung ke pasar tradisional seperti : harga, bisa nawar, lengkap. Sehingga konsumen tertarik berkunjung.Sedangkan nilai hedonik (hedonic value) yang dapat dinikmati konsumen seperti : mood, menikmati, senang, dan nyaman. Hal ini menandakan bahwa pengunjung pada pasar tradisional memiliki pengalaman yang buruk untuk memperoleh nilai-nilai hedonik sehingga menjadi salah satu alasan untuk tidak berkunjung di masa akan datang.

Hal ini juga konsisten dari studi eksplorasi dimana salah satu alasan responden beralih ke pasar modern karena faktor kenyamanan, dapat mengajak keluarga, santai dan lama-lama, yang tidak mereka temukan di pasar tradisional. Disamping itu juga pengunjung pada pasar modern selain memperhatikan nilai utilitas terkait dengan pemenuhan kebutuhan sehari-harinya juga mempertimbangkan nilai hedonik yang dapat diperoleh ketika berkunjung ke pasar modern, selain pemenuhan kebutuhan keluarga juga faktor kenyamanan, dapat membangkitkan mood yang positif, serta menyenangkan yang tidak mereka temukan di pasar tradisional.

Hubungan shopping motives terhadap retailer interest, nilai utilitarian dan hedonic value sangat mempengaruhi respon konsumen untuk berkunjung dan berbelanja, yang selanjutnya dapat di indikasikan dan memperjelas bahwa kehadiran berbagai atribut ritel yang melahirkan atau membangkitkan nilai hedonic tidak serta 
merta menggeser nilai utilitarian sejalan dengan berbagai penelitian sebelumnya (Arnold \& Reynod,2003; Richins,1997)

Berdasarkan uraian di atas, maka penulis dapat menggambarkan paradigma penelitian yang akan menjelaskan hubungan antara variabel -variabel yang akan diteliti yaitu, sebagai berikut:

\section{Paradigma Penelitian}

(Pola hubungan antara variabel bebas dan variabel terikat)

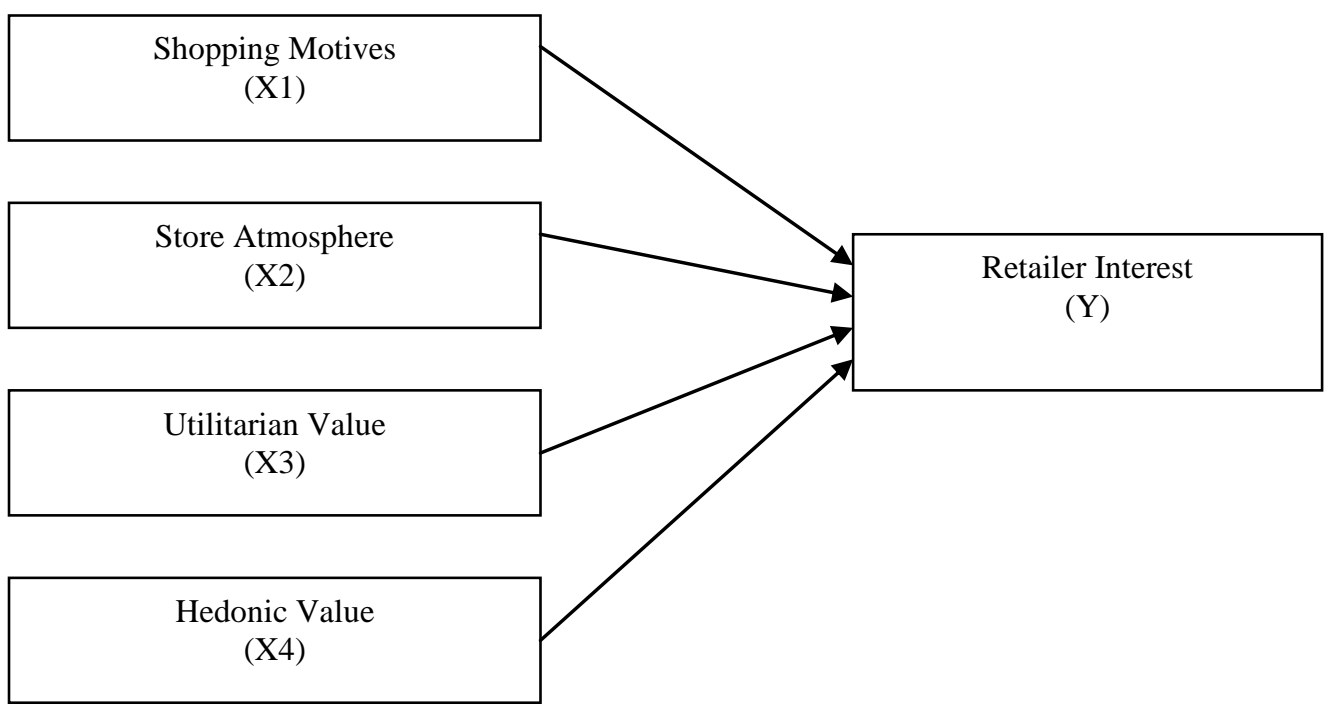

\section{Hipotesis}

Menurut Sudjana, (2002) hipotesis adalah asumsi atau dugaan mengenai sesuatu hal yang dibuat untuk menjelaskan hal itu yang sering dituntut untuk melakukan pengecekannya.

Berdasarkan uraian permasalahan diatas, maka penulis mengajukan hipotesis sebagai berikut :

1. Nilai Utilitarian mempunyai hubungan positif terhadap pembentukan retailerinterest

2. Nilai Hedonic mempunyai hubungan positif terhadap pembentukan retailer interest

3. Shopping Motives mempunyai hubungan positif terhadap pembentukan retailer interest

4. Retail Atmosphere mempunyai hubungan positif terhadap pembentukan retailer interest

\section{METODE PENELITIAN}

\section{Definisi Operasional dan Pengukuran Variabel}

1. Retailer Interest (Y), adalah : ketertarikan atau keinginan konsumen untuk datang mengunjungi ritel atau pusat-pusat perbelanjaan ,2.

2. Shopping Motives (X1), adalah : motivasi berbelanja konsumen yang dipengaruhi berbagai locus of control. 
3. Store Atmosphere (X2) adalah : lingkungan atau kondisi factual dari berbagai atribut yang ditampilkan suatu ritel atau pusat perbelanjaan.

4. Utilitarian Value (X3), adalah : nilai fungsional (utilitarian) yang dirasakan oleh konsumen terkait dengan pemenuhan kebutuhannya.

5. Hedonic Value (X4), adalah : nilai hedonis (emosi) yang dirasakan oleh konsumen pada saat akan, sedang atau telah mengkonsumsi suatu produk.

Untuk lebih jelas lagi mengenai paparan yang dikemukakan oleh penulis mengenai definisi operasional dan pengukuran variabel-variabel dalam penelitian ini, maka dapat dilihat pada tabel $: 2$ berikut ini:

\section{Definisi Operasional Variabel dan Indikator Variabel}

\begin{tabular}{|c|c|c|c|}
\hline KONSTRUK & DEFINISI & INDIKATOR & AUTHOR \\
\hline $\begin{array}{l}\text { Shopping } \\
\text { Motives } \\
\text { (X1) }\end{array}$ & $\begin{array}{l}\text { Motivasi berbelanja konsumen } \\
\text { yang dipengaruhi oleh } \\
\text { berbagai locus of control }\end{array}$ & $\begin{array}{l}\text { 1. Role shopping } \\
\text { 2. Value shopping } \\
\text { 3. Social shopping }\end{array}$ & $\begin{array}{l}\text { Arnold } \quad \& \\
\text { Reynolds }\end{array}$ \\
\hline $\begin{array}{l}\text { Store } \\
\text { Atmosphere } \\
\text { (X2) }\end{array}$ & $\begin{array}{l}\text { Lingkungan atau kondisi } \\
\text { factual dari berbagai atribut } \\
\text { yang ditampilkan suatu ritel } \\
\text { atau pusat perbelanjaan }\end{array}$ & $\begin{array}{l}\text { 1.Store layout } \\
\text { 2. General } \\
\text { interior } \\
\text { 3.Exterior } \\
\text { 4.Service } \\
\text { facilities } \\
\text { 5.Employee } \\
\text { abilities }\end{array}$ & $\begin{array}{l}\text { Bermans \& } \\
\text { Evans (1995) }\end{array}$ \\
\hline $\begin{array}{l}\text { Utilitarian } \\
\text { Value (X3) }\end{array}$ & $\begin{array}{l}\text { Nilai fungsional (utilitarian) } \\
\text { yang dirasakan oleh konsumen } \\
\text { terkait dengan pemenuhan } \\
\text { kebutuhan }\end{array}$ & $\begin{array}{l}\text { 1.Need } \\
\text { 2. Value } \\
\text { 3.Benefit }\end{array}$ & $\begin{array}{l}\text { Mano \& Oliver } \\
\text { (1993) }\end{array}$ \\
\hline $\begin{array}{l}\text { Hedonic Value } \\
\text { (X4) }\end{array}$ & $\begin{array}{l}\text { Nilai hedonis (emosi) yang } \\
\text { dirasakan oleh konsumen pada } \\
\text { saat akan, sedang atau telah } \\
\text { mengkonsumsi suatu produk }\end{array}$ & $\begin{array}{l}\text { 1.Pleasure } \\
\text { 2.Arousal } \\
\text { 3.Enjoyful } \\
\text { 4.Good mood }\end{array}$ & $\begin{array}{l}\text { Mano \& Oliver } \\
(1993)\end{array}$ \\
\hline $\begin{array}{l}\text { Retailer } \\
\text { Interest }(\mathbf{Y})\end{array}$ & $\begin{array}{l}\text { Ketertarikan atau keinginan } \\
\text { konsumen untuk datang } \\
\text { mengunjungi ritel atau pusat- } \\
\text { pusat perbelanjaan }\end{array}$ & $\begin{array}{l}\text { 1.Intrigued } \\
\text { 2.Interest } \\
\text { 3.Fascinated } \\
\text { 4.Curious }\end{array}$ & $\begin{array}{l}\text { Jones \& } \\
\text { Reynolds (2006) }\end{array}$ \\
\hline
\end{tabular}

\section{HASIL PENELITIAN}

Berdasarkan hasil pengujian asumsi klasik, maka dapat dikatakan bahwa model analisis berganda memenuhi seluruh asumsi klasik OLS (Ordinary Least Square), karena terbebas dari gejala Heteroskedastisitas, Multikolinieritas, Autokorelasi dan Normalitas. Dengan menggunakan bantuan komputer program SPSS versi 18 sebagai alat bantuan dalam analisis diperoleh hasil sebagai berikut: 
ANOVA ${ }^{\mathrm{a}}$

\begin{tabular}{|ll|l|l|l|l|l|}
\hline \multicolumn{2}{|l|}{ Model } & $\begin{array}{l}\text { Sum of } \\
\text { Squares }\end{array}$ & df & $\begin{array}{l}\text { Mean } \\
\text { Square }\end{array}$ & F & Sig. \\
\hline \multirow{2}{*}{1} & Regression & 10,688 & 4 & 2,672 & 3,504 &, $009^{\mathrm{b}}$ \\
& Residual & 125,812 & 165 &, 762 & & \\
& Total & 136,500 & 169 & & & \\
\hline
\end{tabular}

a. Dependent Variable: Y

b. Predictors: (Constant), X4, X1, X3, X2

\section{Coefficients $^{\mathbf{a}}$}

\begin{tabular}{|c|c|c|c|c|c|c|}
\hline \multirow{2}{*}{\multicolumn{2}{|c|}{ Model }} & \multicolumn{2}{|c|}{$\begin{array}{l}\text { Unstandardized } \\
\text { Coefficients }\end{array}$} & \multirow{2}{*}{$\begin{array}{l}\text { Standardized } \\
\text { Coefficients } \\
\text { Beta }\end{array}$} & \multirow[t]{2}{*}{$t$} & \multirow[t]{2}{*}{ Sig. } \\
\hline & & B & Std. Error & & & \\
\hline \multirow{5}{*}{1} & (Constant) & 10,881 & 1,207 & & 9,016 &, 000 \\
\hline & $\mathrm{X} 1$ &, 026 &, 076 &, 027 &, 337 &, 736 \\
\hline & $\mathrm{X} 2$ &, 001 &, 077 &, 001 & ,013 & ,990 \\
\hline & $\mathrm{X} 3$ &,- 053 &, 073 &,- 056 &,- 715 &, 476 \\
\hline & $\mathrm{X} 4$ & ,281 & ,076 &, 282 & 3,683 &, 000 \\
\hline
\end{tabular}

berikut:

Berdasarkan tabel diatas maka dapat disusun persamaaan regresi sebagai

$\mathrm{Y}=10,881+0,026 \mathrm{X} 1+0,001 \mathrm{X} 2+(-, 053) \mathrm{X} 3+0,281 \mathrm{X} 4$

Dari persamaan regresi diatas maka dapat diketahui bahwa besarnya konstanta adalah 10,881, berarti bahwa asumsi variabel independen bernilai 0 maka retailer interest berada pada posisi 10,881. Sementara itu koefisien X1 diperoleh sebesar 0,026, koefisien X2 diperoleh sebesar 0,001, koefisien X3 diperoleh sebesar-053 sedangkan koefisien X4 sebesar 0,281.

Berdasarkan persamaan regresi tersebut dapat dilihat bahwa variabel X1( Shopping motives) ,X2( Store Atmosphere) dan X4 (Hedonic Value) mempunyai arah positif terhadap retailer interest dan X3( Utilitarian Value) mempunyai arah berlawanan atau negatif terhadap retailer interest.

\section{Pengujian Hipotesis}

Selanjutnya sesuai dengan rancangan pengujian hipotesis pada bab sebelumnya, maka pengujian hipotesis ketertarikan masyarakat berbelanja di bisnis retail, adalah sebagai berikut:

1. Pengaruh Shopping Motives ( Motivasi berbelanja ), Store Atmosphere( lingkungan berbelanja), Utilitarian Value (nilai kegunaaan/manfaat) dan Hedonic Value ( Nilai Emosi) terhadap retailer interest.(Pusat perbelanjaan retel) secara simultan

Hipotesis secara bersama dapat dilakukan dengan menggunakan statistik uji F. Pengujian hipotesis tersebut dilakukan dengan uji dua arah dengan 
menggunakan tingkat signifikansi $=0,05$ dan derajat bebas(k) dan (n-k-1). Pengujian dilakukan dengan cara membandingkan antara nilai $\mathrm{F}$ hitung dengan $\mathrm{F}$ tabel dengan kreteria :

Jika F hitung < F tabel : Ho diterima atau Ha ditolak

Jika F hitung $>\mathrm{F}$ tabel : Ha diterima atau Ho ditolak

Berdasarkan hasil analisis regresi yang disimpulkan pada tabel sebelumnya, menunjukkan nilai $\mathrm{F}$ hitung adalah 3,504 dan nilai $\mathrm{F}$ tabel pada alfa $=0,05$

Dan derajat bebas 4 dan 165 adalah 2,37. Jadi $\mathrm{F}$ hitung=3,504>F tabel =2,37. Hal ini berarti bahwa Ho ditolak dan Ha diterima pada tingkat signifikansi alfa $=0,05$. Dari hasil pengujian ternyata variabel utilitarian value (nilai kegunaan/manfaat) terbuang dari model regresi, sehingga variabel shopping motives, store atmosphere dan hedonoc value berpengaruh terhadap retailer interest.

2. Pengaruh Shopping Motives ( Motivasi berbelanja), Store Atmosphere( lingkungan berbelanja), Utilitarian Value (nilai kegunaaan/manfaat) dan Hedonic Value ( Nilai Emosi) terhadap retailer interest.(Pusat perbelanjaan retel) secara parsial

Sama halnya dengan pengujian hipotesis diatas, maka untuk menguji hipotesis secara parsial dapat dilakukan dengan menggunakan statistik uji t. Pengujian hipotesis tersebut dilakukan dengan uji dua arah dengan menggunakan alfa=0,05 dan derajat bebas (n-k-1). Selanjutnya pengujian dilakukan dengan cara membandingkan antara nilai t-hitung dengan nilai t-tabel dengan kreteria keputusan adalah:

Jika thitung <t-tabel: Ho diterima atau Ha ditolak

Jika t hitung $>$ t-tabel : Ha diterima atau Ho ditolak

Pengaruh Shopping Motives ( Motivasi berbelanja ), Store Atmosphere( lingkungan berbelanja), Utilitarian Value (nilai kegunaaan/manfaat) dan Hedonic Value ( Nilai Emosi) terhadap retailer interest.(Pusat perbelanjaan retel) secara parsial

\begin{tabular}{|l|l|l|l|l|}
\hline $\begin{array}{l}\text { Variabel } \\
\text { independen }\end{array}$ & T hitung & T tabel & Signifikansi & Kesimpulan \\
\hline $\begin{array}{l}\text { Shopping } \\
\text { Motives (X1) }\end{array}$ & 0,337 & 1,960 & 0,736 & Signifikansi \\
\hline $\begin{array}{l}\text { Store } \\
\text { Atmosphere } \\
(\mathrm{X} 2)\end{array}$ & 0,013 & 1,960 & 0,990 & Signifikansi \\
\hline $\begin{array}{l}\text { Utilitarian } \\
\text { Value (X3) }\end{array}$ & -715 & 1,960 & 0,476 & $\begin{array}{l}\text { Tidak } \\
\text { Signifikan }\end{array}$ \\
\hline $\begin{array}{l}\text { Hedonic Value } \\
(\mathrm{X} 4)\end{array}$ & 3,683 & 1,060 & 0,000 & Signifikan \\
\hline
\end{tabular}

Berdasarkan tabel diatas, dapat diketahui bagaimana pengaruh atau hubungan antara shopping motives, store atmosphere, utilitarian value dan hedonic value terhadap retailer interest. 


\section{PEMBAHASAN}

Ketertarikan Masyarakat berbelanja di bisnis retail atau pasar modern di Kota Medan dipengaruhi oleh beberapa variabel atau faktor, dan dilihat dari pennyebaran kuesioner dan penggolahan data dengan menggunakan program SPSS, maka dapat diketahui pada umumnya masyarakat berbelanja di pasar modern atau bisnis retail dengan berbagai macam motivasi, hal ini dapat terlihat bahwa variabel X1 ( Shopping motives) berpengaruh positif dan signifikan. Hal ini dapat kita lihat bahwa pada umumnya masyarakat berbelanja ingin berbelanja dengan harga yang jelas, daya beli disesuaikan dengan kemampuan masing-masing dan memiliki selera yang beraneka ragam.

Sedangkan lingkungan perbelanjaan atau Store Atmosphere (X2), juga bernilai positif dan signifikan, hal ini dapat dilihat bahwa masyarakat berbelanja memiliki rasa aman, nyaman dan bersih.Pusat perbelanjaan retel memberikan fasilitas yang dapat memuaskan para pengunjung dan pengunjung nantinya diharapkan kembali lagi berbelanja.

Selanjutnya faktor utilitarian value (X3) atau nilai kegunaan/manfaat dari hasil penggolahan data di peroleh hasil yang negatif dan tidak signifikan, hal ini terlhat bahwa pada umumnya masyarakat yang menggunakan pasar modern untuk berbelanja tidak merasakan manfaat atau kegunaan barang berbeda dengabn lainnya, sehingga karena barang yang ditawarkan di pasar modern sebenarnya manfaat dengan barang yang sejenis sama, dan faktor ini menjadi variabel yang hilang atau terbuang. Dan hal ini karena hasil pengujian dengan bantuan SPSS tidak memperoleh hasil yang signifikan.

Berikutnya pada variabel hedonic value (X4)atau nilai emosi terhadap produk, memiliki pengaruh yang positif dan signifikan, hal ini terlihat dari beberapa pusat perbelanjaan retel bahwa apabila ada program diskon terhadap beberapa jenis produk yang ditawarkan, maka pada umumnya masyrakat berlomba-lomba untuk mendapatkan barang atau produk tersebut, sehingga pusat perbelanjaan menjadi ramai pengunjungnya.

Berdasarkan pengamatan peneliti terhadap beberapa bisnis retel di Kota Medan, pada umumnya masyarakat atau konsumen sebagai pemakai akhir dari suatu produk sudah dapat atau bisa membedakan dimana mereka berbelanja dengan mendapatkan barang berkualitas tai harga terjangkau, dengan adanya promosi dan diskon produk yang ditawarkan oleh pasar modern atau bisnis retel.

\section{KESIMPULAN}

Ketertarikan mayarakat berbelanja di bisnis retel khususnya di Kota Medan dipengaruhi oleh berbagai faktor yaitu : Motivasi berbelanja (Shopping Motives), Lingkungan belanja yang bersih dan nyaman (Store atmosphere), nilai kegunaan/ manfaat dari produk yang ditawarkan (Utilitarian value) dan nilai emosi terhadap produk (Hedonic value).

Faktor yang paling dominan atau besar yang mempengaruhi masyarakat berbelanja di bisnis retel adalah lingkungan belanja yang nyaman, bersih, sejuk dan banyak permainan bagi pengunjung baik anak-anak, remaja, dewasa dan manula, sehingga pusat perbelanjaaan bisa juga dijadikan arena untuk rekreasi.

Faktor lainnya yang menjadi alasan masyarakat berbelanja di bisnis retel dan berpengaruh secara positif dan signifikat adalah motivasi berbelanja dan nilai emosi terhadap suatu barang, sedangkan faktor lain yang kurang atau tidak mempengaruhi 
masyarakat berbelanja di bisnis ritel adalah utilitarian value atau nilai kegunaan/manfaat dari prouk yang ditawarkan, dimana dalam hal ini masyarakat menilai bahwa kegunaaan produk yang sejenis sama saja, hanya tempat pembeliaannya saja yang berbeda, sehingga pada faktor ini memperoleh angka negatif dan tidak berpengaruh signifikan.

\section{DAFTAR PUSTAKA}

Arnold and Reynolds (2003), 'Hedonic Shopping Motivation",Journal of Retailing;Vol 79.

Barret,V, (1995.), "How to Conduct and Analyze Real Estate Market and Feasibility Studies, 'Prentice Hall press.

Berman B, Evans JR(1998), "Retail Management; a strategic approach. $7^{\text {th }}$ ed.Englewood Cliffs, NJ: Pretice-Hall.

Clore, Gerald L, Andrew Ortony, \& Mark A Foss (1987),'The Psychological Foundation of the Affective Lexicon," Journal of Personality and Social Psichology,53(October)751-755.

Dawson, Scott;Bloch, Peter H ;Nancy M (1990), "Shopping Motives, Emotional States, and Retail Outcomes,"Journal of Retailing; Vol 66.

Griffin et al,(1994), "Measuring Hedonic and Utilitarian Shopping Value," Journal of Consumer Research;20.

Hair, et al (2006), Multivariate Data Analysis, Prentice Hall, Englewood Cliffs, New Jersey

Jones and Reynolds (2006), "The role of Retailer intereston shopping behavior" ,Journal of Retailing; Vol 82.

Mano,Haim;Oliver Richard L(1993), "Assessing the dimensionality and structure of the consumtion experience: Evaluation, Feeling and Satisfaction," Journal of Consumer Research;20.

Reynolds et al (2002), "Traditional malls vs factory outlet : comparing shopper typologies and implications for retail strategy". Journal of Business Vol. 55

Richard Michona, Jean-Charles Chebatb,L.W Turleyc (2005), Mall atmospherics : the interaction effects of the mall environment on shopping behavior," Journal of Research Vol.58

Richins Marsha L (1997), Measuring emotions in the consumption experience," Journal of Consumer Research Vol.24

Spies et al. (1997), "Store Atmosphere, Mood, and Purchasing Behavior", International Journal of Research in Marketing; Vol 14

Szymanski S David, M. and David H. Henard (2001). "Customer Statisfaction: A Metaanalysis of the Empirical Evidence," Journal of the Academy of Marketing Science, 29 (1), 16-35

Wesley et.al (2006)," Consumer decision-making styles and mall shopping behavior: Building theory using exploratory data analysis and the comparative method". Journal of Business Research Vol.59 